\title{
A reciprocal legitimation: Corrado Gini and statistics in fascist Italy
}

\section{Giovanni Favero}

To cite this article: Giovanni Favero (2017): A reciprocal legitimation: Corrado Gini and statistics in fascist Italy, Management \& Organizational History, DOI: 10.1080/17449359.2017.1363509

To link to this article: http://dx.doi.org/10.1080/17449359.2017.1363509

$$
\text { 曲 Published online: } 14 \text { Aug } 2017 .
$$

Submit your article to this journal $₫$

Q View related articles $\square$

View Crossmark data $\nearrow$ 


\title{
A reciprocal legitimation: Corrado Gini and statistics in fascist Italy
}

\author{
Giovanni Favero \\ Department of Management, Università Ca' Foscari Venezia, Venice, Italy
}

\begin{abstract}
This article deals with the relationship between science and politics and in particular with the reciprocal legitimation process involving research schools and political regimes. It focuses on the case of Italian statistics during the early twentieth century. Its emergence as both an independent scientific field and a national research school, in fact, went together with the rise of nationalism and the establishment of the fascist regime. The paper uses the biography of Corrado Gini to analyze the process of mutual legitimization between science and politics under fascism. Gini's academic and professional careers show in fact how actors and ideas could compete through their ability to alter the status of the discipline, the technical functions it was assigned, and to attract funds in a changing political context. Gini, as an institutional entrepreneur, was able to make his research school hegemonic in Italy by leveraging the need for scientific legitimation of new state policies during World War I and under fascism. The reinterpretation he provided of his career after the end of World War II is crucial both to deconstructing this process and to shedding light on the postwar de-legitimation of Italian statistics.
\end{abstract}

\section{KEYWORDS}

Reciprocal legitimation; science and politics; history of statistics; scientific biography; fascist Italy

\section{Introduction}

The literature on the cultural practices of legitimation (Lounsbury and Glynn 2001) has extensively discussed the cognitive and sociopolitical issues at stake in these processes. However, aside from the metaphorical use of political mobilization as a model, much of the literature on legitimacy in entrepreneurship ignores or takes for granted the role of politics and the state (Suchman 1995; Suddaby, Bitektine and Haack 2017). Historical studies on the creation and consolidation of research schools and disciplinary fields highlight instead the crucial role the political context may exert on these processes (for an example see Weingart 1999). What is more, as Bucheli and Kim (2014) highlight, the specific historical characteristics of state legitimacy highly affect, in turn, the legitimizing action that the state itself may exert toward entrepreneurial efforts of any kind. In particular, the role of the scientific legitimation of political power suggests the opportunity to explore the mutual relationship between emerging academic fields or research schools and political regimes. 
The case of the rise of Italian statistics as an independent scientific field in the early twentieth century, and the role that Corrado Gini's research school had in it, here discussed, shows that a mutually reinforcing legitimation process took place between the emergence of Italian statistics and the consolidation of the fascist regime (Prévost 2009a). The claims of statistics and demography over appropriate scientific knowledge in Italy meshed with the 'corporatist' vision of the state and of the economy that was developed under fascism (Favero 2010) and with its pro-natalist population policy (Ipsen 1996; Treves 2001). Statistical classifications, defining what and who counted and how they should be counted, exerted a constitutive effect, reinforcing a particular political vision, and were in their turn legitimated by their official use in the fascist state. Statistics was also legitimated as a technical function of public administration, providing the state with the instruments to manage the Italian population, society and economy in a totalitarian perspective. In a centralized educational system, controlled by ministerial agencies, this allowed statistics to expand its academic scope by taking advantage of its political and administrative 'usefulness'. Such a liaison obviously induced de-legitimation claims from home and abroad, and resulted in the reversal of the academic fortune of statistics in Italy after the end of the fascist regime (Favero 2011).

The above-cited historical literature on Italian statistics has duly highlighted the connection between statistics and politics in fascist Italy, yet the actual working of legitimation mechanisms requires further investigations to be fully understood. Did statistics have inherent features favoring its connection with interventionist and totalitarian regimes? Was it a matter of the peculiar evolution of the discipline in Italy? Or was it the cultural background of Italian politicians and civil servants that made of statistics a favorite technique to manage the problems of an emerging mass society?

The existing studies on elite culture and the development of social sciences in Italy show the presence of a growing nationalistic bias in the academic and scientific milieu since the years preceding World War I (Lanaro 1979; Patriarca 1996; Favero 2001). The active role of individual scholars and their political preferences in framing this peculiar feature of the new social sciences in Italy is also evident (Treves 2001; Prévost 2009b). This article focuses on the establishment of Corrado Gini's research school, and its successful identification with Italian statistics. Gini's biography offers the occasion to analyze in detail the process of legitimation of statistics as an independent discipline in Italy and the function it came to perform in the context of the fascist regime, providing some answers to the questions above.

The next two sections (2) define the concept of'reciprocal legitimation' as a tool to provide historical cognizance to theories of legitimacy, and (3) identify the 'research school' as the unit of analysis, to be inquired through a biographical lens. The subsequent sections distinguish four different moments in Gini's entrepreneurial endeavors, starting (4) with Gini's role as a scholar in the definition of methodological statistics as an independent field. Italian statistics (5) was eventually identified with his research school and connected to the establishment of the fascist regime. Subsequently (6), following a gradual shift in fascist science policy and the emergence of alternative schools in Italian statistics, Gini started new methodological controversies at national and international level, trying to impose a realignment on his positions of Italian statisticians. The radical change in the political context following World War II (7) implied delegitimation of statistics as a politicized science, forcing Gini to reinterpret his scientific career retrospectively in a new light. Finally, the conclusions (8) summarize the historical findings and draw out the implications of this study for a theoretical 
interpretation of mutual legitimation processes between scientific schools and state politics.

\section{Historicizing legitimacy: the reciprocal legitimation of science and politics}

The managerial literature has broadly defined legitimacy as the 'generalized perception or assumption that the actions of an entity are desirable, proper or appropriate within some socially constructed system of norms, values, beliefs, and definitions' (Suchman 1995, 574). Such a general definition has been developed in the last two decades from different perspectives, which identified legitimacy as a property, as a process or rather as a perception. Interestingly, the conceptualization of legitimacy as a property is criticized because of its a-historical essentialism, i.e. the assumption that legitimacy itself, the organization that is legitimized, and the social environment that legitimizes it 'are stable, universal, and enduring properties' (Suddaby, Bitektine and Haack 2017, 458). Theorizing legitimacy as a process offers instead the possibility to investigate the mechanisms of its social construction. However, despite a focus on contextual factors, this approach did not produce a generalized theorization of their role, leading to 'a tendency to conceive processes of legitimation as heroic acts of institutional change', somehow artificially dividing 'actors' from their 'audience' (Suddaby, Bitektine and Haack 2017, 462). A way out from this stalemate has been identified in a definition of legitimacy as a matter of perception of evaluators, whose individual judgments may be suppressed when perceived as not aligned with collective validity judgments, creating an illusion of consensus (Bitektine and Haack 2015). It would then be wrong to infer isomorphism at individual level from collective uniformity (Slater), as 'hidden transcripts' resist hegemonic discourse (Scott 1990).

This paper argues that, aside from this dynamic relationship between individual (micro) and collective (macro) judgments of legitimacy, further feedback mechanisms can be identified in legitimation processes, in particular focusing on the reciprocal relationship between different fields, organizations, and actors. These mechanisms are crucial in explaining not only the collapse of legitimation following the risk of a negative contagion (Suchman 1995, 597), but also the success of institutional entrepreneurship, as they can provide a stable legitimation to new initiatives.

Reciprocal legitimation has not been the subject of explicit consideration in the legitimacy literature. It is possible to define it as an exchange of mutual support that can emerge when an actor or entity is (part of) the audience of (part of) its own audience. The fact that 'legitimation is frequently mutualistic' was in fact highlighted since the early debate on institutional entrepreneurship, yet it was framed as the need to 'act in concert', to resort to 'collective evangelism' (Suchman 1995, 591-597), or to recruit 'the help of subsidiary actors' (Di Maggio $1988,15)$ in order to succeed. The limits of such a strategic interpretation of reciprocal legitimation can explain why, in the legitimacy literature, institutional feedback loops and consequent path dependencies were for a long time poorly understood. However, even most recent theorizations introducing a multi-level perspective do not see the possibility of a reciprocal legitimization between different sources of collective validity, which are narrowly circumscribed to the media, the government, and the judicial system (Bitektine and Haack 2015, 51-52). Such conditions limit the scope of application of the existing theories on legitimacy and legitimation processes to present-day Western liberal-democratic societies. 
The neglect of a wide range of variation in the political and institutional context denotes a lack of 'historical cognizance' (Kipping and Üsdiken 2014a) in the legitimacy literature, as Bucheli and Kim (2014) have shown. This in turn may explain the inattention to reciprocal legitimation processes, which develop historically, are contingent and related to specific periods, and display different features in different contexts. Perhaps only 'historical approaches can provide institutional reflexivity to researchers who, like the phenomenon they study, may suffer from the paradox of embeddedness', as the same Suddaby, Bitektine and Haack $(2017,470)$ argue. Historical rigor and the related attention to context, change over time, causality, complexity, and contingency may then result in a much-needed guard against shortcuts to theoretical development that lose sight of long-term processes and variables, sometimes undergoing unexpected surprises (Perchard, MacKenzie, Decker and Favero 2017).

Taking this perspective at heart, this paper makes the case of a reciprocal legitimation process involving a specific political and institutional regime (fascism and the fascist state) and an emerging academic research field (the 'Italian school of statistics') in interwar Italy. The role that quantification and quantitative methods played historically in the management of social conflicts and in the construction of legitimate forms of modern state has been broadly highlighted in the social studies of science and in the history of social sciences (Porter and Ross 2003; Rottenburg, Merry, Park and Mugler 2015; on statistics in particular see Woolf 1989; Hacking 1990; Porter 1996; Desrosières 2002). However, it has not been examined in the managerial research on legitimacy, which has instead highlighted the legitimating role of language and discourse through persuasion, translation, and narration (Suddaby, Bitektine and Haack 2017, 460). The above-cited literature in the history and sociology of statistics shows that it is clearly possible to argue that quantification itself has been, at least in the last two centuries, a particularly effective strategy of discursive legitimation, different from the other typologies identified by Vaara, Tienari and Laurila (2006). The same literature highlights indirectly the legitimating action that state power exerted in its turn on the scientific development of quantitative methods through the establishment of official technical bodies and the legal recognition of expertise, not to mention the role of the state in regulating the university system.

In this perspective, in interwar Italy we may identify the conditions for a pragmatic exchange between the rational credibility that statistical expertise could provide to the fascist state, and the support of the authoritarian state power to the institutionalization of an emerging national'research school' in statistics. Such an exchange evolved into a procedural legitimation of statistically supported state decisions, and into a structural legitimation of the role of statistics in the education of state officials. The connection between Gini's school of statistics and the fascist state thus ended being taken for granted, so much to persist despite the crisis of Gini's personal relationship with Mussolini.

\section{A biographical approach to the study of a research school}

The concept of 'research school', as elaborated in the history of science (Morrell 1972; Geison 1978; Geison 1993), seems particularly fit to define the scientific entity in search of legitimation in the context under analysis here. Identifying the research school as the unit of analysis shifts the focus from theoretical debates to the institutional innovations in the organization of research work, and on the social context that makes the emergence of new scientific ideas 
possible. However, its application to modern statistics and its political legitimation in a dictatorial context is not immediately obvious. As Secord $(1986,261)$ reminds, 'a research school, like a discipline, is essentially a descriptive category for charting patterns of changing and contingent social relations. Although it cannot explain those patterns in a causal sense, it does suggest fruitful ways of exploring them'.

Most of the existing studies on research schools deal with the development of natural sciences during the nineteenth century. The peculiar political environment of liberal Europe and the complex connection of natural sciences with state policies may explain why such studies somewhat overlooked the role of politics in the legitimation of new fields of scientific inquiry.

Perhaps more importantly, the 'research school' model was developed on laboratory-based disciplines such as chemistry and physiology and, as Kushner (1993) and Geison $(1993,232)$ effectively observe, 'locally constructed experimental systems' seem to be constitutive of research schools.

In such a perspective, Gini's entrepreneurial activism in establishing laboratories of statistics in Italian universities can be interpreted as part of his effort to build a research school in statistics (Prévost 2009a, 60-75). The same is true for his engagement in scientific controversies as instrumental to identify Italian statistics as a distinct research school (Prévost 2009a, 34-57; Geison 1993, 237; Turner 1993).

The focus on Gini as the leader of the main research school in Italian statistics under fascism seems then justified by his own strategic attitude and awareness. He was explicitly using the term 'school' to define Italian statistics as distinguished from other national traditions (Gini 1926a, 1939, 1965; Cassata 2006, 142-148). A last characterizing feature of a research school being in fact the role of its leader, it is also possible to argue that such an attitude was reinforced by the emphasis put by fascist rhetoric on leadership and charisma. So, even the bias toward the importance of the leader's personal characteristics in the 'research school' approach seems to fit with the mutually reinforcing legitimation between fascist politics and Gini's statistical school.

There is however in this approach an evident risk of interpreting the political legitimation of Italian statistics as the result of Gini's sole strategic action, following the interpretation of the events provided in his own writings. The triangulation with independent sources, from other scholars' letters and papers to the official records of national and international organizations, is crucial to put his role back into perspective. Finally, also the factum Gini presented during the purge trial in 1945, reinterpreting retrospectively his own career under the fascist regime, can be used to disentangle the emergent and strategic features of the reciprocal legitimation process between Italian statistics and the fascist regime.

Avoiding getting stuck into the shoes of her subject, the historian can thus make of a biography a moving point of observation on research politics in a specific context. The life of an academic entrepreneur may be used as the narrative thread highlighting the complex interactions that make possible entrepreneurial processes of change.

As Latour (1993) has shown in his book on Louis Pasteur, a leading scholar can be interpreted as an effect, rather than a 'prime mover' (an actor), of the strategies, arrangements, and mobilizations of different entities into a network. However, actor-network theory is far from suggesting that personal agency is not relevant (Latour 2005). Clearly it is relevant, and yet the ability to connect, and to recognize the connection, takes here the place of doing everything - leading, managing, and creating. In this perspective, collective or distributed 
agency becomes the actual source of change, in a process that becomes visible only at a microanalytical level. A similar idea of 'interstitial' entrepreneurship is suggested by the microhistorical reflection on the uses of biography. As Levi $(1989,1334)$ has remarked, 'there is a permanent and reciprocal relationship between biography and context; change is precisely the endless sum of these interactions.' In its turn, the unpredictable variety of individual choices is the result of the inconsistencies and contradictions between different contexts, which authorize the multiplication and diversification of practices. As Seo and Creed (2002) suggested from an institutional perspective, the friction between the different logics in which an actor is embedded opens the way to a diverse range of possible choices, which have in their turn the potential to change these environments by putting them in relationship.

Gini's entrepreneurial role emerges in fact at the intersection of different fields, as science and academia, ideology and the state, business and the economy, the national and international context, where the function of knowledge translator, information intermediary, and power broker are mixed together. The comparison between sources originating from these different contexts is crucial to put into perspective Gini's own narrative and to use his biography to highlight the interactions between science and politics at different levels.

\section{Defining a discipline: Italian methodological statistics}

The first Italian scholar to define statistics as'a branch of logic, namely a method' was Rodolfo Benini $(1901,10)$. In his words, methodological statistics was a 'form of observation and induction appropriate to the quantitative study of phenomena that appear as a plurality or mass of cases' (Benini 1906, 1). Today readers are acquainted with such a definition as obvious. Yet in the late nineteenth century, in Italy as in large part of other countries, the dominant opinion among scholars was that statistics should be rather classified as a social science, focusing on the identification of laws or regularities in the development of human societies. Such a definition of the discipline fitted with its position inside of the university programs in law, where public officials were usually trained.

The new methodological approach determined a different articulation of the teaching of statistics: new textbooks started neglecting more and more the traditional historical and institutional approach to deal with technical problems of data observation, collection, elaboration and analysis, and especially with the correlation and regression methods that were being developed by British mathematical statistics. The knowledge and use of mathematics emerged rapidly as a discriminating element between the 'old' statistics (which resisted inside of university degrees in law) and the 'new' approach (which found better reception in the schools of commerce). Very few of the Italian statisticians educated before of the 'methodological turn' could understand mathematics. Benini was himself an exception because of his experience inside of the central statistical office.

Only with World War I a 'new generation' of statisticians emerged. They were trained in the new methodological and mathematical methods, but also in a changing cultural and political environment. The presence of distinctive generational features was crucial in framing the identity of Italian statisticians as a community and in legitimating their ambitions. They largely adhered to the positions of the nationalist movement, and were able to take on roles of technical responsibility within the administration during the war. This allowed them to demonstrate the effectiveness of their specific quantitative skills not only in the management 
of the war economy but also in developing useful arguments for postwar diplomatic battles (Prévost 2016; Beaud and Prévost 2012, 133-152). The technical success of their engagement during the war was a first important step toward the legitimation of statistical expertise. However, the war also reinforced a specific pattern of relationship between Italian statisticians and the state, defining the usefulness of their discipline in terms of the contribution of its applications to the national interest. The same happened in other fields, as for instance in applied mathematics. Mauro Picone, later a colleague of Gini at the university of Rome and the founder of the National Institute for Computing Applications, stated in his autobiography that the war experience as an engineer in charge of elaborating new ballistic tables convinced him that 'mathematics is not only beautiful, it can be useful as well' (Picone 1972, 8).

In this way, during and immediately after the war, new scholars emerged who dominated the field of statistics until World War Il: among them, Costantino Bresciani Turroni, Giorgio Mortara, Riccardo Bachi, Livio Livi, Marcello Boldrini, Felice Vinci, and especially Corrado Gini, together with his many students. In 1926, Gini was put at the head of Italian official statistics, which the fascist government renovated with the establishment of the Central Statistical Institute (Istituto Centrale di Statistica, from here on Istat). This appointment marked the official recognition of his leading role in Italian statistics, both at scientific and academic level. In fact, Gini more than anyone else had contributed in the previous two decades to legitimate the specificity and autonomy of statistics as a discipline in Italy.

After Benini's foundational definition of 'methodological statistics' as based on mathematics, Gini's 'methodological' contributions on probability (Gini [1911] 2001a) and on the concentration indices (Gini [1911] 1922) were indeed the most scientifically relevant in the field. As Prévost (2009a, 34-57) has shown, the strategic goal Gini was pursuing with these articles was the delimitation of a specific disciplinary field for statistics, in spite of its use of mathematical tools and of their application to the traditional subjects of other social sciences, first of all of economics.

The marginalist revolution in Italian economics had been at first associated with the development of methodological statistics. New statistical methods were discussed in the same journals and collections where marginalist economists published their articles. This link was made evident in the third series of the Giornale degli economisti, started in 1911 under the direction of Giorgio Mortara and Gustavo Del Vecchio, which added the subtitle Rivista di statistica. An emphasis on quantitative methods also distinguished the Italian economists that in the following decades grouped in Milan around the Bocconi University and the Banca Commerciale Italiana.

In such a context, the efforts Gini undertook since 1908 to create a specialized journal of statistics (finally accomplished in 1920 with Metron: see Cassata 2006, 89-96) can be interpreted as part of an effort aimed precisely to emancipate statistics from its role of a sophisticated instrument of economic theory. The creation of specific editorial instruments was an important step in the process of legitimation of the field. At the same time, the control of the new specialized publication outlets was crucial to establish a research school under Gini's leadership.

Gini explained in a letter the strategic meaning of his scientific project. In 1910, comparing his own work on the concentration (or inequality) index with Pareto's distribution law, he stated that his own aim 
was perhaps a little wider [than Pareto's], as I did not limit my inquiry to economic phenomena, but much more modest: I intended only to search for formulas that were useful in practice to study the concentration and the mutual dependence of phenomena, without any pretense that they could describe the variations with great precision in all cases. (letter of Gini to Vladimiro Furlan, September 1910: Pareto 1975, 2, 704-705)

In that same article on concentration indices, Gini precisely identified the limitations that affected the most advanced methods of mathematical statistics and hindered their application to the study of economic and social phenomena. In his opinion, the use of Bravais' correlation and Galton's regression coefficients required 'a so detailed knowledge of the studied phenomena that is not always available'. Hence, the need for 'indices of the distribution of quantitative phenomena and of their mutual relationships that are sensitive enough but may be applied to conventional statistical data avoiding arduous calculations and assumptions that are far from the real world' (Gini [1911] 1922, 4-5; Giorgi 1992).

This way, Gini started taking distance not only from marginalist economics, but also from its preference for the probabilistic and inferential methods of 'Anglo-Saxon statistics'. He identified an alternative solution in the (neo-)descriptive approach that qualified the Italian contribution to statistics, as he would argue in a lecture held at the London School of Economics (Gini 1926a). In that occasion, he proposed a consistent story of the recent evolution of statistical studies in Italy that legitimized the dominance of his research school, at the same time suggesting a national, if not nationalistic, interpretation of scientific positions and debates. The theorization proposed by Gini exerted a crucial role in legitimizing the specific features of statistical research as developed in Italy against existing alternative models.

Gini's (1926a, 707) idea of 'statistics with the least mathematical means possible' was in fact clearly opposed to Fisher's $(1925,1)$ definition of the discipline as 'a branch of applied mathematics' (Cassata 2006, 143-144). He was thus able to mark the boundary between the 'empirical' use made of probability by statisticians versus the 'abstract' and deductive nature of mathematical probability. At the same time, however, as a 'method' based on the use of specific mathematical tools, statistics could boast a higher scientific rigor against applied disciplines, in particular against social sciences with a weaker definition, as sociology. The occupation by statisticians of these areas of study in Italy, and an extension of statistical applications to a wider range of disciplines followed.

\section{Legitimating Gini's research school}

The new relationship between methodological statistics and its empirical applications implied the need for a greater division of scientific work and for a more structured organization. With this aim, Gini himself promoted since prewar years the establishment of university laboratories and institutes of statistics in Cagliari, where he took tenure in 1910, then in Padua from 1913 and in Rome since 1926. Inside a laboratory, professors designed the methodology of research, assistants interpreted the results, and students collected and elaborated data. The model for such an organization of research work was derived from the Laboratory of Political Economy established by the economist Salvatore Cognetti De Martiis in 1893 in the University of Turin, in the premises of Cesare Lombroso's Laboratory of Forensic Pathology (Prévost 2009a, 64-65). The 'mathematical turn' in economics and then in statistics fostered the imitation of the laboratory research methods and practices of natural sciences. The 
creation of the two dominant 'research schools' of marginalist economics and methodological statistics was in part an effect of these institutional dynamics. The emphasis that fascism put on the practical applications of science was also favoring the adoption of the university laboratory as a model for the organization of statistical research. The laboratory made possible to connect a focus on methodology with visible results attracting external supporters and stakeholders. Examples of external collaborations multiply in 1926, when Gini was appointed as the president of the Higher Statistical Council (Consiglio Superiore di Statistica, from here on CSS) supervising the Istat, and moved from the University of Padua to the University La Sapienza in Rome. In the same year, the national industrialists' association (Confederazione nazionale degli industriali, Confindustria) commissioned the publication of the Indici del movimento economico italiano to Gini's Institute of Economic Policy at La Sapienza . Confindustria paid for the publication and the elaboration of the data it provided, following the scheme of the collaboration previously reestablished with the Laboratory of Statistics at the University of Padua. ${ }^{2}$ The first volume of the Indici was in fact completed in Padua, as Mario Saibante wrote to Gini in a letter reporting on the situation in the Laboratory that Gini had left quite abruptly after his appointment in Rome (ACS, Fondo Gini, Corrispondenza, b. 7, Mario Saibante, 25 February 1926).

The contract with Confindustria made available to the laboratories of statistics in Padua and Rome a flow of financial resources that was decisive to develop their activities through the acquisition of books, maps and mechanical and electrical calculators (on Padua, see Pietra 1943). But commercial gains were not the main benefit of this relationship: student placement and political support were certainly more relevant. Some of the students working in Padua and Rome became part of the statistical staff of Confindustria and its sister association of joint-stock companies (Assonime): Saibante became himself the director of the Assonime's statistical office in 1927, and of Confindustria's survey and study office in 1936 (Barberi 1958).

The collaboration with Confindustria is mostly interesting as it shows how the reciprocal legitimation between Italian school of methodological statistics and the fascist state may be crucial to attract the consensus of other actors in a process that the legitimacy literature broadly labels as 'constituency building' (Bitektine and Haack 2015, 59). For the fascist regime in the mid 1920s, the support of industrialists was decisive, and Gini found himself to be at the same time the 'statistician of confidence' of both the industrialists and the Duce.

He was in contact with Confindustria since before World War I, as his brother, the engineer Aldo Gini, had a role in the establishment of the industrialists' association. One of his pupils in Cagliari, Giovanni Dettori, was also collaborating with the association. In the early postwar years, Gini (1923) published an article in the association's journal arguing against the estimation of real industrial wages resulting from the statistics of the National Fund for Industrial Accidents (Inail). Mortara (1922), as a member of the Inquiring Commission on Industry, had used these data to argue that the average monthly wage for industrial workers did not grow after the war as much as the industrialists were claiming on the basis of the nominal increase in hourly wages.

In the same years Confindustria was financing the elaboration by Gini's statistical laboratory in the University of Padua of the data on workers, worked hours and hourly wages collected from the accounting books of its associated businesses. These data, and Gini's (1923) detailed methodological discussion of the faults of Inail statistics, became politically strategic in 1926, when Mussolini decided the stabilization of the Italian lira at 'quota 90', i.e. 
90 liras per pound sterling, re-evaluating it much further than what Confidustria advocated. In order to obtain the association's support to this deflationary move, the fascist government needed to assure the industrialists that it would apply wage cuts reducing nominal labor costs in due proportion. The assessment of real wages should thus be based on data provided by Confindustria itself in order to fit with the 'superior needs of production', as Gini himself (1926b) argued in an international publication. Their official level should then be calculated comparing hourly wages in industrial businesses with a measure of the cost of living taken from factory outlets. Following these considerations, in 1928 Confindustria started publishing a monthly series of the hourly earnings of industrial workers in its Bollettino di notizie economiche. Gini's Istat would then use these data to calculate an official index of wages that was published from 1930 in the Bollettino dei prezzi and in the Bollettino mensile di statistica (Favero 2010, 321-330).

The statistical measurement of prices and wages was a critical stake in the political governance of the Italian economy: since 1926 fascist unions, put under the government control, approved a series of wage cuts based on technical considerations deriving from official data. During the 1920s, statistics played then a fundamental political role in settling the power relationships between the fascist regime and Italian industrialists. Gini's scientific authority, and the work performed by colleagues, assistants, and students in the university laboratories in Padua and Rome, was instrumental to such a settlement. His double allegiance contributed to make of him the ideal candidate to lead the reorganization of Italian official statistics when the Istat was established in 1926. The reorganization of official statistics was part of the political and administrative authoritarian transformation of the state organization devised by the newly established fascist regime. In the trade-off between legality and efficiency (Melis 1988), fascism neatly privileged the second in order to gradually reinforce the power of central state authority and its control of population and economic dynamics. This entailed the multiplication of new autonomous institutes directly supervised by the government and by scientific advisory councils, following a model that had been already experimented in the prewar years for some technical bodies (Cassese 1981; see also the essays in Varni and Melis 1999).

At first, then, the Istat was put under the political authority of the head of government and under the scientific authority of the CSS, which brought together university professors of statistics, ministry officials, and representatives of trade associations. Gini was in fact appointed as its chair. In 1929, however, in a further step toward centralization, he was put at the presidency of the Istat under Mussolini's direct authority, while the CSS was maintained as an advisory body. From such a position, Gini's authority reverberated on academic dynamics, fostering the expansion of statistical teaching and the dominance of his research school inside of the discipline.

During the 1920s, the academic position of statistics as a discipline was also affected by the university reform introduced on September 1923 (Royal decree 2102) by the Minister of Public Education, Giovanni Gentile. This deregulated the organization of university studies, allowing an expansion of the applications of methodological statistics to a wider range of fields, but making the course of statistics optional in the Faculty of Law, where it was traditionally placed as compulsory (Gini 1926a, 704). After an ephemeral multiplication of statistical courses within scientific programs, statisticians were able to consolidate their presence in the newly established Faculties of Political Science (Alvazzi Del Frate 2000), in this way confirming their traditional attention for the education of civil servants. 
The establishment in 1927 of undergraduate biennial schools of statistics in Padua and in Rome can also be interpreted in this same perspective. In 1930, the diploma they issued became a legal requirement to be hired in the statistical staff of Italian public administrations (Gini 1926a, 704; Favero and Trivellato 2011,43-44). Gini as the president of the Istat actively promoted such a measure as a tool to ensure a standardization of procedures and methods in the production of statistical data through the selection of an educated and specialized staff.

At the same time, the Istat was unsuccessfully trying to impose such standards through an active coordination of the statistical work performed inside of different administrations, or through their advocated centralization (Beaud and Prévost 1997, 441; see as an example D'Autilia 1999). Institutional conflicts followed, leading Gini to ask for the support of Mussolini and, this failing, to finally resign in 1932 (Leti 1996, 150-151). A detailed reconstruction of the growing difficult relationship between Gini and the Fascist government administration is provided by Cassata $(2006,92-101)$.

Interestingly, Gini would declare in 1945, in the defense report against his purge from an academic body, that he'resigned in 1928, considering as accomplished the mission he undertook to rebuild the organization of Italian statistics, yet his resignation was accepted only in $1932^{\prime 3}$. Gini's authoritarian management of the Istat had in fact led many distinguished scholars as Livio Livi, Ugo Giusti and Guglielmo Tagliacarne to leave the institute in 1928, questioning his scientific legitimacy as the main representative of Italian statistics. Conflicts between Italian statisticians in the late 1920s corresponded to the emergence of different scientific positions. These found expression in the creation of different local 'research schools' based in university laboratories and publishing their own statistical journals. Livi established in 1929 in Florence the Barometro economico italiano, which adopted the Harvard approach to economic forecasts, against which Gini (1926c) had explicitly taken position. In the same year, Felice Vinci established in Bologna the Rivista italiana di statistica, which soon added corporatist economics and finance to its title, and Luigi Amoroso and Alberto De Stefani as editors, finally becoming the Rivista italiana di scienze economiche (Prévost 2009a, 72-75).

As Gini's political influence declined after his resignation from the Istat in 1932, divisions emerged also at the academic level. Gini and his pupils privileged a 'methodological' approach, in the framework of an 'organicist' view of social sciences (Favero 2004). Other statisticians were more interested in the autonomous development of quantitative methods suitable for different applied disciplines, from quantitative economics to demography. A debate launched in 1935 on the Barometro economico italiano on whether to establish an association of Italian statisticians made these different visions of the discipline explicit (Tagliacarne 1935). They implied also a different way of conceiving the relationship between academic statisticians and the practitioners who worked in private and public institutions, from insurance companies to the research centers of banks up to the Istat. Indeed, the problem of defining the relationship between official statistics and the future association emerged as the main obstacle to the constitution of the latter in these years (Leti 1990, 38-67; Cocchi and Favero 2009, 216).

\section{Fascist policy and Italian statistics}

The relationship between basic science and the practical application of scientific knowledge in Italy became during the early and mid 1930s the matter of conflict and disillusion in many 
disciplinary fields. The political attention for technical improvements and efficiency, together with the substantial public investments in applied research during the 1920s, had lured many scientists into a collaboration with the fascist state (Maiocchi 2003). The support was however reciprocal, or mutual, as argued here and already suggested in other terms (Saraiva and Wise 2010).

Most of the political campaigns (or 'battles', as they were defined at the time) that fascism started, from autarky to pronatalism, implied in fact an involvement of scientific expertise. This triggered processes of more or less intense reciprocal legitimation between individual 'research schools' and the regime. One example is the mobilization of Nazareno Strampelli's plant genetics in the context of the 'battle for grain' and national self-sufficiency (Saraiva 2011). The antimalarial campaign even offered political support to discredited scientific positions with tragic outcomes, as in the experiment conducted by Giacomo Peroni and Onofrio Cirillo with toxic mercury therapy on hundreds of peasants during the late 1920s (Snowden 2009, 143-146). Less horrific but perhaps having longer term consequences was the clear preference of the regime for the practical applications of science rather than for the development of fundamental research. Following Mussolini's impatience with the long procedures of scientific inquiry, Alberto Missiroli, the leading Italian malariologist, declared that 'the need today is to extend the practical application of the knowledge that we already have rather than to broaden what we know' (Missiroli 1929, 118). As the disappointment of the representatives in Italy of the Rockefeller Foundation confirms (Donelli and Serinaldi 2003), such a position discouraged the investments in medical research on malaria, dispersing the competences accumulated in Italy in the previous decades (Snowden 2009, 177-180).

The problem of a scarce and episodic attention of the fascist state for basic research applies to almost any scientific field, from mathematics to chemistry. The case of the development of applied mathematics in the interwar years (Nastasi 2006), when no university appointment was made in algebra, is an example of this attitude (Tazzioli 2011, 412). The attempt to establish a stronger relationship between chemical science and industry for the production of new materials in the context of autarky generally failed because of the lack of investments in fundamental research (Cerrutti 2001; Ciardi 2011, 453-454), yet much depended from the actors involved. Whereas Nicola Parravano (1936), the main representative of Italian chemistry at institutional level, was a promoter of the priority of practical applications, the physicist, senator and former minister Orso Mario Corbino was able to obtain funds for basic research too. He not only established the first chairs in theoretical physics, to which Enrico Fermi was appointed (Bordoni 2011, 431), but also launched a research program that was soon to produce important results at international level (Battimelli, Paoloni and De Maria 2001).

Some of the scientists involved in the making of science policy in fascist Italy were then able to convey state funding to theoretical research through the promotion of large-scale applied projects that attracted the interest of the regime. In this way, they made up for the lack of interest of the fascist government for the long-term perspectives in the development of scientific knowledge. At the same time, they enjoyed of an unprecedented authority and power in their scientific field, becoming in fact the brokers of the relationship of reciprocal legitimation that was established between fascism and some scientific research schools. The case of Gini is an excellent example of this process. As seen above, his ability to connect in an organic system the role of methodological statistics, its applications to demography, 
economics and sociology, and the creation of new institutions was crucial in explaining the success of his research school.

Yet this success was questioned in the early 1930s, following a change in the regime attitude toward science. The vicissitudes of the National council of research (Consiglio Nazionale delle Ricerche, CNR) shed light on the national and international implications of this change, and can explain the shifting position of leading scientists as Gini (Paoloni and Simili 2001).

From the inter-allied scientific collaboration during World War I originated the establishment of the International research council (IRC) in 1919. This was created as a double federation of general national scientific councils and of disciplinary international scientific unions, aggregated by field in international councils. Political instability and the opposition of part of the university academia prevented the establishment of the CNR in Italy until 1923, when Vito Volterra was elected as its president. In the place of Volterra, following the fascist reformation of the CNR in 1927, Mussolini appointed Guglielmo Marconi, the famous inventor of radio-telegraphy and entrepreneur. This choice was the expression of the anti-academic turn of the regime, and made explicit a focus on applied science and technology. From the standpoint of the fascist state, the new CNR was instrumental in modifying the trend in university research toward applications of national interest. However, its scientific legitimation still derived from the participation of the main Italian scientists into its disciplinary national committees, which were being established and becoming members of international scientific unions (Paoloni 2011, 191).

It was at this time that Gini attended the first world congress on population in Geneva in 1927, where the International Union for the Scientific Investigation of Population Problems (IUSIPP) was created as part of the Social Science Research Council (SSRC), one of the disciplinary international scientific unions. Gini established in 1928 the Italian committee for population studies (Comitato Italiano per gli Studi di Popolazione, CISP), and became one of the three vice-presidents of the IUSIPP, under the presidency of the American biologist Raymond Pearl. In a 1928 meeting of the IUSIPP in Paris, Gini was able to fix its first congress in Rome in 1931. Yet doubts on the possible politicization of the meeting and the evident conflict between the then dominant neo-malthusianism and the natalist positions of Italian, French, and German members of the IUSIPP convinced the president of the SSRC, the American statistician Edwin B. Wilson, not to finance the congress in Rome. Pearl then moved it to London, the CISP exited the IUSIPP, and Gini organized in 1931 an alternative congress in Rome with the participation of scholars from Germany, France, and the United States (Cassata 2006, 26-33).

Again, Gini's move paralleled the exit in 1931 of the Italian CNR from the International Council of Scientific Unions (ICSU, as the IRC had been renominated). The CNR underwent a new reformation that extended its powers and made of it the highest technical council of the state, and the pivot for the intended creation of a military-industrial complex of research (Paoloni 2011, 194, 201). The decision to discontinue the membership in international scientific institutions was justified as the result of the failure of the scientific internationalism of the 1920s. Following these events, Gini pushed forward his idea of an 'Italian school of statistics' as an example of 'fascist science', in which science and politics found a synthesis. As scientific theories followed national interests, a properly national science should be elaborated to support population and economic policies (Gini 1931). 
The CISP maintained the financial support of the state until Gini's resignation from the Istat in 1932. However, budget cuts were soon after made following Mussolini's disappointment for the results of the population policy inspired by Gini. Later in the 1930s, the racist turn in fascist demographic policy, which accompanied and followed the Ethiopian War, enhanced the divisions among Italian statisticians and interacted with their international relationships.

In 1934 Gini's committee was finally able to launch Genus, a journal of demography and eugenics sponsored by the CNR, where Gini found the support of the vice-president Amedeo Giannini, a senior official of the Foreign ministry. In 1935, however, Livio Livi attended the congress of the IUSIPP in Berlin, was nominated as one of its vice-presidents, and was officially authorized to accept the position in 1936 by the Italian Government. As a consequence of this, in 1937 a new Advisory committee for population studies (Comitato Consultivo per gli Studi di Popolazione, CCSP) was established as the new national reference for the IUSIPP, in which German scientists had a prominent role (Bertaux 2002, 237-250). Under the directions of the next congress of the IUSIPP, held in 1937 in Paris, the Italian Government put Livi's CCSP in charge of studying the Italian population to assess the viability of a new population policy on imitation of the German model, which included economic incentives and racial selection (Treves 2001, 331-334). In the same year, after Marconi's unexpected death, Mussolini appointed the military chief of staff Pietro Badoglio at the presidency of the CNR, clearly marking a further turn toward the engagement of scientific research with autarky and possibly a war on the side of nazi Germany (Maiocchi 2003, 261-264). In the following two years, measures providing economic support to families and marriage were introduced in Italy together with both 'preventive' and 'repressive' eugenic measures that culminated with the laws on the racial discrimination of Jews in 1938 (Treves 2001, 260-274).

In 1938, the CCSP became the Italian society of demography and statistics (Società Italiana di Demografia e Statistica, SIDS), which gathered many scholars active in applied statistics around Livio Livi, Felice Vinci and Franco Savorgnan, Gini's successor at the head of the Istat. In response to this initiative, in January 1939 a group of pupils of Gini established the Italian society of statistics (Società Italiana di Statistica, SIS) (Leti 1990, 67-68). The conflict between two 'research schools' and their competition for political support seemed the main motive for the formal establishment of the two associations. Competition overcame the obstacles that made it impossible in 1935 to establish a single association.

The founding group of the SIS gathered around the Supplemento statistico to the journal of corporative studies Nuovi problemi di politica, storia ed economia (NPPSE). The latter had been established in Ferrara in 1930 under the direction of Nello Quilici and with the support of Italo Balbo, at the time Minister of Aviation and later governor of the Libyan colony. The Supplemento started its publications only in 1935, and collected contributions from scholars of the universities of Ferrara and Padua. Gaetano Pietra, Gini's long-time assistant and successor in Padua, dean of the Faculty of Political sciences from 1939 to 1941, was the director of the Supplemento and became the first president of the SIS, which established its seat in Padua (Pietra 1939; Cocchi and Favero 2009, 226-233).

The association could enjoy the support of Gini's connections with the CNR, the Assonime, Confindustria, the National insurance institute (INA), and the Bank of Italy, yet was mainly financed by the University of Padua and the local Council of corporations (as fascism redenominated the former Chamber of commerce). The entry of Italy into the war in June 1940, the death of Nello Quilici together with Balbo in Libya, and the subsequent closure of the 
NPPSE offered Gini the opportunity to take direct control of the SIS and move its seat to Rome.

Gini found then in the association the ideal forum to revive the debate on statistical methods in contrast with the most recent developments of 'Anglo-Saxon' mathematical statistics (Gini [1939] 2001b, [1943] 2001c). He started a scientific polemic against the inferential use of significance tests and confidence intervals proposed by Ronald Fisher and Jerzy Neyman (together with Karl Pearson) in their articles, which were the basis of sampling procedures. Gini used a Bayesian argument to dismantle the reliability of statistical inference, making reference to the fallacy of 'drawing from the inconsistency of an observation with the null hypothesis an argument in favour of the hypothesis one champions' (Prévost 2016, 160-161). As Prévost has shown, this 'controversy' (as Gini saw it) was the final outcome of the 'strategic' use that Gini made of methodological debate, which during the war took on a heavier nationalistic flavor. Gini in fact recruited into his new 'project' different scientific positions, including the (neo-)descriptive approach he had defined as specific of Italian statistics (Gini 1926a; 1939), the skepticism about sampling methods that was widespread among official statisticians (Beaud and Prévost 1998), and the subjective, neo-Bayesian definition of probability formulated by Bruno de Finetti, of which he did however not fully appreciate the innovativity (Piccinato 2011; Giorgi and Gubbiotti 2016, 5). The idea of a conflict between national 'schools' undoubtedly contributed to make Italian statisticians suspicious toward statistical inference. Such an attitude would last well beyond the end of the fascist regime (Cassata 2006, 147), and hindered the adoption of sampling methods until the 1950s.

The 'autarkic' turn in Italian statistics described above went together with the closure in the late 1930s of most of the university courses in statistics that had been opened in the 1920s. The centralist reorganization of university programs, introduced in 1935 by the minister Cesare De Vecchi, discriminated between mandatory and optional courses, at the same time reducing the total number of courses. Statistics was erased in most of the programs, except for the ones in Political science and in Law, where however it was optional. It remained mandatory in the new programs in Economics resulting from the transformation into university faculties of the former institutes or schools of commerce.

In 1936 Gini replied by establishing the new Faculty of Statistics at the University of Rome, resulting from the merger of the mathematical School of Statistics and Actuarial Science and his Institute of Statistics and Economic Policy. The new faculty resulted from an academic alliance with financial mathematics and probability theory, involving in particular Francesco Paolo Cantelli and Guido Castelnuovo. The establishment of an autonomous faculty assured the reproduction of academic staff in statistics. Yet such a move strengthened the hierarchical relationship between the statistical method and its applications, thus confirming a privileged connection between statistics and the social sciences that in theory the methodological approach had made obsolete.

Even after his resignation from Istat in 1932, Gini went on supporting any possible synergy between the university training of statisticians, the recruitment of technical staff in the civil service, and the organization of official statistics. Such an effort was part of a strategic project aiming at making the applications of methodological statistics essential for the construction of a corporatist and totalitarian system for the control of the population and of the economy, which the fascist regime was trying to build in the late 1930s. Gini's pupils and associates made such intentions even more explicit with the project of a 'corporatist statistics'(Pietra 1934; Fortunati 1936). The increasing politicization of the discipline was made evident when 
new courses of 'applied' statistics were made mandatory in all the universities of Italy following the racial laws. A new generation of young statisticians thus entered then the university teaching courses of 'Comparative demography of the races' or 'Colonial sociology' (Cocchi and Favero 2009, 222-223).

\section{Coping with delegitimation, in retrospective}

This evolution somehow established the conditions for the decline of Italian statistics in postwar years. The involvement of Italian statisticians in the ideological and political choices of the fascist regime stirred a reaction of postwar governments and of the same university system. Abruptly, what had been a major factor of legitimacy became an element of delegitimation, starting a process in which the 'successes of the past become impediments to the future' (Suchman 1995, 597). A paradoxical result of the postwar ostracism against statistics was not the expulsion of most statisticians from Italian universities. Given the outcome of the purge process in Italy (Woller 1997), they maintained their place. Yet no more statisticians were appointed for some years, in this way reinforcing the academic dominance of the elder generation at least until its retirement.

At the same time, in official statistics the introduction of sample surveys and the reorganization of data collection to fill in the framework of national accounting were imposed to Italy as a condition to participate in the European Recovery Program. In the postwar decade, statistical innovation in Italy was then led by official statistics, while the new methods continued to stir suspicion and widespread resistance among university statisticians, following the lasting influenced of Gini's positions and the intransigence of some of his pupils (Favero and Trivellato 2000, 269-280).

Gini himself insisted, even in the late 1950s, on a reactionary view of modern progress as an actual decadence (Cassata 2006, 183-188). The connection he established between sampling, decolonization, and decadence is evident for instance in his claim that

Giving up the effort towards a complete and quantitative knowledge of phenomena, which was once the aim of statistical surveys, we have accepted the expedient of sampling, this way conforming to the backward conditions of the underdeveloped countries to which such surveys were extended. (Gini 1959, 1141)

In this perspective, Gini's rearward battle in the 1950s for the revitalization of the International institute of sociology against the International Sociological Association established by the United Nations Educational, Scientific, and Cultural Organization (Unesco) can be interpreted as part of his last project for the construction of a reactionary social science, which Francesco Cassata $(2006,194-213)$ has reconstructed in detail.

Yet interpreting such a project as the result of a coherence of Gini's political and scientific positions would be misleading. When Rome was liberated by the American army in June 1944, Gini started in fact elaborating a new role for himself and his competences in the frame of the new context. In a new book on 'post-war problems' (Gini 1944), he resumed from some previous articles the idea of the United States as a 'laborist society', built with the force of European immigrants (Gini 1940). In the new context, his proposal was a geopolitical and socio-biological reunification of the United States and Europe as an alternative to Asian and African immigration. This idea found political realization in the charter of the Unionist Italian Movement that he wrote (Cassata 2005). However, in the first elections after the war on June 1946 , the movement did not succeed to elect any representative in the Constituent Assembly. 
What is more, the Italian political situation remained uncertain, as the communist and socialist parties remained part of government majority.

This situation, and the suspension from teaching that followed the start of a purge trial against him in November 1946, pushed him to explore the possibility to emigrate. During 1945 he wrote to Henry H. Sonnabend at the University of Witwatersrord in South Africa, to F.W. Nichol at IBM and to Alfred J. Lotka at the Metropolitan Life Insurance Company in the United States, to Gunnar Dahlberg in Sweden and to Benoy Sarkar at the Bengali Institute of Economics, asking information and support to find lecturing or research jobs (Cassata 2006, 149-151).

At the same time, he was mobilizing the members of his widespread research school to collect signatures in support of his defense from university colleagues in Rome, Naples, Milan, Padua, and Bologna. ${ }^{4}$ Gini's defense strategy followed two main lines, as highlighted by Cassata $(2004,89-90)$. The first, trying to identify as apolitical his scientific contributions, was evidently falsified by many of the statements that were included in such contributions. The second line was to argue that he was collaborating with the regime as a technician but remained loyal to his scientific principles. This position somehow reflects his genuine belief and his peculiar concept of science. In the end, he was able to provide a 'normalizing account' (Suchman 1995, 597-599) that allowed a partial re-legitimation of his research school in postwar Italy, and the restoration of large part of his academic power. The writings of his pupils in a collective volume published in his honor demonstrate the allegiance to this account of a widespread network of 'Ginian' scholars both inside the university and official statistics (Castellano 1960). Even the most recent celebrations in the 50th anniversary of his death repeat the arguments of Gini's defense (Giorgi and Gubbiotti 2016, 7-9), despite many historical studies that have put them into critical perspective (Cassata 2004, 2006; Prévost 2009a).

What is interesting here is the way Gini was able to re-frame his whole career as a scientist, making of this idea the thread connecting disparate episodes. Gini reinterpreted the strategic relationship of reciprocal legitimation between science and politics that was highlighted above into an instrumental collaboration. In this way, he not only bent the events to his purposes, but also highlighted some aspects of his attitude that were crucial to his own identity as a scientist. It is worth then to cite some examples of the considerations he made from a document he presented against the purge from an academic body, ${ }_{1}^{5}$ as he repeated the same statements in most of the papers he produced in his defense.

On his relationship with the fascist party, Gini alleged that his party membership was assigned him honoris causa without consulting him, this way declining any responsibility. ${ }^{6}$ He also mentions his successful efforts to retain at the Istat several employees who were not members of the party or even were renown as antifascists, opposing the tentative politicization of the institute. The reconstruction of the events of 1930 and 1931 proposed by Cassata (2006, 92-101) confirms his assertions. A defense of the technical and scientific autonomy of the Istat from political interference was in fact coherent with the strategy of reciprocal legitimation he was pursuing between the Italian school of statistics and fascist politics. This may in fact work only as long as the two poles remained independent. In the same perspective, it is possible to interpret Gini's (1942) article criticizing the appointment of university professors by the Ministers of Education without competition. ${ }^{7}$

Gini had also an easy game in demonstrating that his opinions on population policy were different from the measures adopted by the fascist regime during the $1930 \mathrm{~s}^{8}$ that he did 
not stick to the anti-Semitic policy and dissolved the board of the journal Metron rather than expelling its Jewish members, ${ }^{9}$ that he was against the entrance of Italy into World War II, ${ }^{10}$ and that he offered protection to colleagues and employees during the Nazi occupation. ${ }^{11}$

However, the tentative representation of his conflicts with the regime as a proper opposition to fascism becomes unrealistic when he describes his minority report in the Commission for the revision of the Constitution as a defense of parliamentary democracy, ${ }^{12}$ denying his radical aversion to the latter (Prévost 2001). In the same way, his opposition to the war did not prevent Gini (1941) from attacking the weakness of democratic countries. He also betrayed his positions on racism (which would resurface in the 1950s) when he declared that, as the president of the Italian society of genetics and eugenics, he fought against racial discrimination 'among civilized populations'.13

The convergence between Gini's 'Italian school of statistics' and fascism was not simply the result of an instrumental collaboration: it was rather emphasizing a nationalistic view of science and providing technocratic strength to an authoritarian regime.

\section{Conclusion}

The last paragraph shows one of the most evident implications of this paper, which focuses on both the proper political dimension of the legitimation of new research schools and on the scientific legitimation of political regimes and their policies. The case study of Italian statistics in the early twentieth century and of Corrado Gini's scientific career offers an unusual perspective on the problem. Retrospectively, Gini's reaction to the political changes connected to the end of World War II sheds light on the limits of a possible reinterpretation of an academic enterprise. Somehow, the effort to disentangle the scientific development of his career from his involvement with a defeated political regime provides a measure of the level of reciprocal legitimation, and the constraints resulting from this process.

In order to draw from this case some theoretical considerations, however, it is necessary to assess the idiosyncrasy of the mechanism of reciprocal legitimation between science and politics here identified in the case of interwar Italian statistics. Resuming the general historical questions posed in the introduction may be useful in this perspective.

Was such a relationship with politics a peculiarity of statistics? In part, it was. The function statistics has performed as a tool of government, but also as a matter of political conflict, has been widely emphasized in the historical literature (Porter 1994; Desrosières 2002; Stapleford 2009). Many studies highlight also the contradictions arising in totalitarian contexts between statistical rigor and governmental manipulations of data (Ipsen 1996; Blum and Gousseff 1997; Tooze 2001). Even in the case of Gini, despite his personal agreement with totalitarian politics, scientific rigor sometimes brought him to resist political interference. This attitude was crucial to maintain the scientific legitimation of Gini's research school, but also to allow it to perform a legitimating role on the fascist state.

The involvement of research schools and scholars in other disciplines in a special relationship with fascism has been discussed above. Different degrees of instrumentality and political interference distinguish some cases from others, yet a common trait is the selection of scientific applications directly contributing to the national interest. Is it possible to identify such a feature as a peculiarity of Italian statistics too? A strong attention for the issues concerning the nation, its government and administration characterizes in fact the history of statistics in Italy since the nineteenth century (Sofia 1988; Patriarca 1996; Favero 2001; Prévost 
2009a), culminating in the above-mentioned nationalism of the generation of Italian statisticians that emerged in the early twentieth century.

On the other hand, it is also possible to trace back to the late nineteenth century the spread among the high ranks of Italian state bureaucracy of a culture that valued quantification as a privileged tool for government. From the 1870 s to the 1890 s, the central statistical office in Rome was in fact employing as 'statistical officials' a number of brilliant university graduates. Most of them made their later career through the ranks of administration, in politics and in business, becoming an influential group inside of the Italian ruling class in the early twentieth century (Marucco 1996, 44-49). This may explain how an emphasis on the role of statistics may find support in different milieus during the interwar period. The confidence that both state officials and trade representatives put in a quantitative assessment of conflictual matters allowed Gini to find a favorable ground when offering the technical legitimation of statistics to the corporatist political fixing of wage levels, which made possible for industrialists to accept Mussolini's deflationary policy in the late 1920s.

The peculiarity of the case results then historically grounded in the specific configuration of the fascist regime, whose totalitarian grip of Italian society depended from the consent of relevant interest groups (Gentile 2008), and in the singular concept of science that was proper of Gini's demographic and sociological theory, whom a reviewer accused to 'put a pseudo-scientific foundation under a nationalistic complex' (Reuter 1931, 648).

Such a peculiarity, however, does not prevent the possibility to draw some general considerations, insofar as it is common with any historical case. A first finding is that the political context in which the emergence of a new research school or field happens matters a lot in the configuration the latter takes. An important implication of this is that the general models explaining the historical development of science are contingent and may find a limiting scope condition in the political regime to which they make reference. Academic entrepreneurship has a relationship with politics, not only because it is largely a matter of 'political' negotiation and conflict, but also because state politics itself affects the mechanisms of legitimation of disciplines and schools. In turn, the scientific legitimation of political regimes takes a different color following the kind of disciplines and schools involved.

The co-evolution of political regimes and related research schools finds its origin in the gradual shift of the mechanism of reciprocal legitimation from pragmatic exchange to taken-for-grantedness. What is interesting in this process is its final invisibility, resulting from the cognitive lock-in of scientific procedures and state regulations, establishing their relationship as obvious. Their reciprocal legitimation remains in fact implicit and unquestionable if set against the presentist frame of most of the legitimacy theoretical literature (Hartog 2015). This literature usually takes for granted the 'social paradigm' (Handa 1986) of liberal democracy, together with the scientist'research tradition' (Laudan 1977) that became dominant in the social sciences since the 1960s. Quantification was a crucial element in the process of legitimation of this tradition and in de-legitimating historical and institutional approaches, as for management studies Kipping and Üsdiken (2014b, 37-38) have shown.

In this context, the contribution of an historical approach to the debate on legitimacy and legitimation acquires a critical function, questioning the presumed universality of theoretical models, putting into perspective obvious assumptions, and showing the contingent and contextual quality of elements that are taken for granted as a result of historical dynamics. If addressed in historical perspective, successful processes of reciprocal legitimation 
emerge in fact retrospectively as one of the mechanisms at the origin of cognitive embeddedness and institutional stability.

\section{Notes}

1. Here and below, where not stated otherwise, the translation into English of quoted texts in other languages is made by the author of this article.

2. Payments to the Laboratory of Statistics of the University of Padua are documented in the Central State Archive in Rome (from here on ACS), Fondo Gini, Corrispondenza, b. 1, Confederazione Generale dell'Industria. The first volume of the Indici was in fact completed in Padua, as Mario Saibante wrote to Gini in a letter reporting on the situation in the Laboratory that Gini had left quite abruptly after his appointment in Rome (ACS, Fondo Gini, Corrispondenza, b. 7, Mario Saibante, 25 February 1926).

3. ACS, Pubblica Istruzione, Direzione Generale dell'Istruzione Superiore, Professori Universitari Epurati (1944-1946), b. 16 (Gini), Letter to the Istituto veneto di scienze lettere e arti, 11 January 1946, Allegato 4.

4. University of Bologna, Department of Statistics, Archive of the journal Statistica, Lascito Fortunati, f.'prof. Corrado Gini', letter 15 November 1945.

5. ACS, Pubblica Istruzione, Direzione Generale dell'Istruzione Superiore, Professori Universitari Epurati [1944-1946], b. 16 [Gini], Letter to the Istituto veneto di scienze lettere e arti, 11 January 1946: from here on, Gini-IVSLA.

6. Gini IVSLA, Allegato 1.

7. Gini IVSLA, Allegato 8.

8. Gini IVSLA, Allegato 9.

9. Gini IVSLA, Allegato 8.

10. Gini IVSLA, Allegato 1.

11. Gini IVSLA, Allegato 12.

12. Gini IVSLA, Allegato 9.

13. Gini IVSLA, Allegato 9.

\section{Disclosure statement}

No potential conflict of interest was reported by the author.

\section{Notes on contributor}

Giovanni Favero is an associate professor in economic and business history at the Ca' Foscari University of Venice, in the Department of Management. His research interests focus on the history of quantification processes in the long term, with an emphasis on the historical construction and interpretation of statistical data concerning population, business and the economy. More recently, he got involved into accounting history and in the methodological debate on historical approaches to management and entrepreneurship studies.

\section{References}

Alvazzi Del Frate, P. 2000. "Tra diritto e politica: le facoltà di scienze politiche e la formazione della burocrazia in Italia." In Burocrazia a scuola: per una storia della formazione del personale pubblico nell'otto-novecento, edited by A. Varni and G. Melis, 249-265. Turin: Rosenberg \& Sellier.

Barberi, B. 1958. "Mario Saibante, 1902-1958." Review of the International Statistical Institute 26 (1-3): $171-172$. 
Battimelli, G., G. Paoloni, and M. De Maria. 2001. L'istituto Nazionale di Fisica Nucleare: storia di una comunità di ricerca. Bari: Laterza.

Beaud, J.-P., and J.-G. Prévost. 1997. "La forme est le fond: la structuration des appareils statistiques nationaux (1800-1945)." Revue de synthèse 118 (4): 419-456.

Beaud, J.-P., and J.-G. Prévost. 1998. "The Politics of Measurable Precision: The Emergence of Sampling Techniques in Canada's Dominion Bureau of Statistics." Canadian Historical Review 79 (4): 691-725.

Beaud, J.-P., and J.-G. Prévost. 2012. Statistics, Public Debate and the State, 1800-1945. London: Pickering \& Chatto.

Benini, R. 1901. Principi di demografia. Florence: Barbera.

Benini, R. 1906. Principi di statistica metodologica. Turin: Utet (Biblioteca dell'Economista [fifth series] 18).

Bertaux, S. 2002. Entre ordre social et ordre racial: Constitution et développement de la démographie en France et en Italie, de la fin du XIXe siècle à la fin des années cinquante. PhD diss.: European University Institute.

Bitektine, A., and P. Haack. 2015. “The 'Macro' and the 'Micro' of Legitimacy: Toward a Multilevel Theory of the Legitimacy Process." Academy of Management Review 40: 49-75.

Blum, A., and C. Gousseff, eds. 1997. "Demographic and Social Statistics (Russia-USSR): Policies, Administrators and Society." Cahiers du Monde Russe 38 (4): 441-627.

Bordoni, S. 2011. “Caratteri e stagioni della fisica." In Storia d'Italia. Annali 26. Scienze e cultura dell'Italia unita, edited by F. Cassata and C. Pogliano, 417-440. Turin: Einaudi.

Bucheli, M. and J.U. Kim. 2014. "The State as a Historical Construct in Organization Studies." In Organizations in Time: History, Theory, Methods, 241-262. Oxford: Oxford University Press.

Cassata, F. 2004. "Cronaca di un'epurazione mancata (luglio 1944 - dicembre 1945)." Popolazione e storia 5 (2): 89-119.

Cassata, F. 2005. "America, 'stirpe di lavoratori': I'antiamericanismo nel pensiero di Corrado Gini." Teoria politica 21 (3): 159-171.

Cassata, F. 2006. Il fascismo razionale: Corrado Gini fra scienza e politica. Rome: Carocci.

Cassese, S. 1981. "Giolittismo e burocrazia nella'cultura delle riviste.'In Storia d'Italia. Annali 4. Intellettuali e potere, edited by C. Vivanti, 475-549. Turin: Einaudi.

Castellano, V. 1960. Studi in onore di Corrado Gini. Rome: Università di Roma "La Sapienza", Istituto di Statistica.

Cerrutti, L. 2001.“La chimica." In Per una storia del Consiglio Nazionale delle Ricerche, edited by L. Paoloni and R. Simili, 1000-1042. Bari: Laterza.

Ciardi, M. 2011. "Fortune e sfortune della chimica." In Storia d'Italia, Annali 26, Scienze e cultura dell'Italia unita, edited by F. Cassata and C. Pogliano, 441-464. Turin: Einaudi.

Cocchi, D., and G. Favero. 2009. “Gli statistici e la 'questione della razza!'. In Le leggi antiebraiche del 1938, le società scientifiche e la scuola in Italia (Roma, 26-27 novembre 2008), 207-35. Rome: Accademia Nazionale delle Scienze detta dei XL.

D'Autilia, M. L. 1999. "La formazione e la pratica dei tecnici della statistica ufficiale tra le due guerre." In Burocrazie non burocratiche: il lavoro dei tecnici nelle amministrazioni tra Otto e Novecento, edited by A. Varni and G. Melis, 19-38. Turin: Rosenberg \& Sellier.

Desrosières, A. 2002. The Politics of Large Numbers: A History of Statistical Reasoning. Cambridge, MA: Harvard University Press.

Di Maggio, P. J. 1988. "Interest and Agency in Institutional Theory." In Institutional Patterns and Organizations, edited by L. G. Zucker, 3-32. Cambridge, MA: Ballinger.

Donelli, G., and E. Serinaldi. 2003. Dalla lotta alla malaria alla nascita dell'Istituto di Sanità Pubblica: il ruolo della Rockefeller Foundation in Italia, 1922-1934. Bari: Laterza.

Favero, G. 2001. Direzione di statistica e municipi nell'Italia liberale. Padua: II Poligrafo.

Favero, G. 2004. "Corrado Gini and Italian statistics under fascism." II pensiero economico italiano 12 (1): 45-59.

Favero, G. 2010. “La statistica dei salari industriali in periodo fascista." Quaderni Storici 45: 319-357.

Favero, G. 2011. “La statistica fra scienza e amministrazione."In Storia d'Italia. Annali 26. Scienze e cultura dell'Italia unita, edited by F. Cassata and C. Pogliano, 703-735. Turin: Einaudi.

Favero, G., and U. Trivellato. 2000. "II lavoro attraverso gli 'Annali': dalle preoccupazioni sociali alla misura della partecipazione e dei comportamenti nel mercato del lavoro." In Statistica ufficiale e storia d'Italia: 
gli "Annali di statistica" dal 1871 al 1997, edited by P. Geretto, 225-304. Rome: Istat. (Annali di Statistica [tenth series] 21).

Favero, G., and U. Trivellato. 2011. “La statistica nell'Università di Padova: un percorso emblematico dalla Restaurazione all'età repubblicana." Rivista di Storia Economica 27 (1): 21-60.

Fisher, R. A. 1925. Statistical Methods for Research Workers. London: Oliver and Boyd.

Fortunati, P. 1936. “Anagrafe corporativa e statistica corporativa." Supplemento statistico ai Nuovi problemi di politica, storia ed economia 2 (2): 20-50.

Geison, G. L. 1978. Michael Foster and the Cambridge school of physiology: The Scientific Enterprise in Late-Victorian society. Princeton: Princeton University Press.

Geison, G. L. 1993. "Research Schools and New Directions in the Historiography of Science." Osiris 8: 226-238.

Gentile, E. 2008. "Fascism and the Italian Road to Totalitarianism." Constellations 15 (3): 291-302.

Gini, C. 1922. Indici di concentrazione e di dipendenza (1911). Turin: Utet. (Biblioteca dell'Economista [fifth series] 20).

Gini, C. 1923. "Sul livello dei salari reali nel dopoguerra in Italia in confronto al loro livello prebellico." Rivista di politica economica 13: 359-384.

Gini, C. 1926a. "The Contributions of Italy to Modern Statistical Methods." Journal of the Royal Statistical Society 89 (4): 703-724.

Gini, C. 1926b. "Appendix G." In Italy's International Economic Position, edited by C. McGuire. London: Macmillan.

Gini, C. 1926c. "La riunione del Comitato di esperti per la questione dei barometri economici indetta dalla Società delle Nazioni." Indici del movimento economico italiano 1 (4): 1-20.

Gini, C. 1931. Le basi scientifiche della politica della popolazione. Rome: Studio editoriale moderno.

Gini, C. 1939. "Caratteristiche e posizione internazionale della statistica italiana."In per il Progresso delle Scienze, Un secolo di progresso scientifico italiano. vol. 1, edited by Società Italiana, 245-252. Rome: Società italiana per il progresso delle scienze.

Gini, C. 1940. "Una società lavorista." Rivista di politica economica 30 (6): 433-460.

Gini, C. 1941. "La lotta attuale tra popoli conservatori e popoli espansionisti e l'evoluzione organica delle Nazioni." Archivio di Studi Corporativi 12 (3): 379-456.

Gini, C. 1942. "Sulla riforma delle Facoltà di Scienze Politiche." Civiltà Fascista 10 (2): 1-18.

Gini, C. 1944. Problemi del dopoguerra. Rome: Migliaresi.

Gini, C. 1959. "Progresso o decadenza? Gli effetti della tecnica sulla devoluzione delle società civili contemporanee." Rivista di Politica Economica 49 (7): 1133-1159.

Gini, C. 1965. "On the Characteristics of Italian Statistics." Journal of the Royal Statistical Society. Series A (General) 128 (1): 89-109.

Gini, C. 2001a. "Considerazioni sulla probabilità a posteriori e applicazioni al rapporto dei sessi nelle nascite umane (1911)." In Statistica e induzione/Induction and Statistics, edited by C. Gini, 3-25. Bologna: Clueb.

Gini, C. 2001 b. "I pericoli della statistica (1939)." In Statistica e induzione/Induction and Statistics, edited by C. Gini, 27-70. Bologna: Clueb.

Gini, C. 2001c. "I testi di significatività (1943)'"' In Statistica e induzione/Induction and Statistics, edited by C. Gini, 75-118. Bologna: Clueb.

Giorgi, G. M. 1992. Il rapporto di concentrazione di Gini: genesi, evoluzione ed una bibliografia commentata. Siena: Libreria editrice.

Giorgi, G. M., and S. Gubbiotti. 2016. "Celebrating the Memory of Corrado Gini: A Personality Out of the Ordinary." International Statistical Review. Advance online publication. Doi: 10.1111/insr.12196

Hacking, I. 1990. The Taming of Chance. Cambridge: Cambridge University Press.

Handa, M. L. 1986. “Peace Paradigm:Transcending Liberal and Marxian Paradigms." Paper presented at International Symposium on Science, Technology and Development, New Delhi, March 20.

Hartog, F. 2015. Regimes of Historicity: Presentism and Experiences of Time. New York: Columbia University Press.

Ipsen, C. 1996. Dictating Demography. Cambridge: Cambridge University Press.

Kipping, M., and B. Üsdiken. 2014a. "History in Organization and Management Theory: More Than Meets the Eye." The Academy of Management Annals 8 (1): 535-588. 
Kipping, M., and B. Üsdiken. 2014b. "History and Organization Studies: A Long-term View." In Organizations in Time: History, Theory, Methods, 33-55. Oxford: Oxford University Press.

Kushner, D. 1993. "Sir George Darwin and a British School of Geophysics." Osiris 8: 196-223.

Latour, B. 1993. The Pasteurization of France. Cambridge, MA: Harvard University Press.

Lanaro, S. 1979. Nazione e lavoro: saggio sulla cultura borghese in Italia (1870-1925). Venice: Marsilio.

Latour, B. 2005. Reassembling the Social: An Introduction to Actor-Network-Theory. Oxford: Oxford University Press.

Laudan, L. 1977. Progress and its Problems: Towards a Theory of Scientific Growth. Berkeley: University of California Press.

Leti, G. 1990. "Verso una Società nazionale di statistica". In Atti del convegno "Statistica e società" Pisa, 9-10 ottobre 1989, 9-72. Società Italiana di Statistica: Pisa.

Leti, G. 1996. L'Istat e il Consiglio superiore di statistica dal 1926 al 1945. Rome: Istat (Annali di Statistica [tenth series] 8).

Levi, G. 1989. “Les usages de la biographie." Annales, Histoire, Sciences Sociales 44 (6): 1325-1336.

Lounsbury, M., and M. A. Glynn. 2001. "Cultural Entrepreneurship: Stories, Legitimacy, and the Acquisition of Resources." Strategic Management Journal 22 (6-7): 545-564.

Maiocchi, R. 2003. Gli scienziati del Duce: il ruolo dei ricercatori e del CNR nella politica autarchica del fascismo. Rome: Carocci.

Marucco, D. 1996. L'amministrazione della statistica nell'Italia unita. Bari: Laterza.

Melis, G. 1988. Due modelli di amministrazione tra liberalismo e fascismo: burocrazie tradizionali e nuovi apparati. Rome: Ufficio Centrale per i Beni Archivistici, Divisione studi e pubblicazioni.

Missiroli, A. 1929. Lezioni del prof. Alberto Missiroli [Scuola Superiore di Malariologia]. Rome: Stabilimento cromo-lito-tipografico.

Morrell, J. 1972. "The Chemist Breeders: The Research Schools of Liebig and Thomas Thomson." Ambix 19 (1): 1-46.

Mortara, G. 1922. "Sulle variazioni dei salari nell'industria italiana dal 1913 al 1922." Rassegna della Previdenza sociale 10 (4): 1-32.

Nastasi, P. 2006. "I primi quarant'anni di vita dell'Istituto per le Applicazioni del Calcolo 'Mauro Picone.'” Bollettino dell'Unione Matematica Italiana. Sezione A: Ia matematica nella società e nella cultura 9 (3): 3-244.

Paoloni, G. 2011. "Il Consiglio Nazionale delle Ricerche: origini e sviluppi." In Storia d'Italia Annali 26 Scienze e cultura dell'Italia unita, edited by F. Cassata and C. Pogliano, 177-201. Turin: Einaudi.

Paoloni, G., and R. Simili, eds. 2001. Per una storia del Consiglio Nazionale delle Ricerche. 2 vols. Bari: Laterza.

Pareto, V. 1975. Correspondance 1890-1923, edited by G. Droz: Busino. Génève.

Parravano, N. 1936. "Il fascismo e la scienza." Nuova Antologia 71: 3-12.

Patriarca, S. 1996. Numbers and Nationhood. Cambridge: Cambridge University Press.

Perchard, A., N. MacKenzie, S. Decker, and G. Favero. 2017. "Clio in the Business School: Historical Approaches in Strategy, International Business and Entrepreneurship." Business History. Advance online publication. doi: 10.1080/00076791.2017.1280025

Piccinato, L. 2011. “Gini's Criticisms to the Theory of Inference: A Missed Opportunity." Metron 69 (1): $101-117$.

Picone, M. 1972. La mia vita. Rome: Tipografia Bardi.

Pietra, G. 1934. Primi lineamenti di statistica corporativa. Padua: Tipografia Antoniana.

Pietra, G. 1939. "La Società Italiana di Statistica." Supplemento statistico ai Nuovi problemi di politica, storia ed economia 4 (4): 1-2.

Pietra, G. 1943. "L'Istituto di Statistica della R. Università di Padova." Statistica 3: 311-317.

Porter, T. M. 1994. "Making Things Quantitative." Science in Context 7 (3): 389-407.

Porter, T. M. 1996. Trust in Numbers. Princeton: Princeton University Press.

Porter, T.M., and D. Ross, eds.2003 The Modern Social Sciences. Vol. 7 of The Cambridge history of science. Cambridge: Cambridge University Press.

Prévost, J.-G. 2001. “Une pathologie politique." Revue Française d'Histoire des Idées Politiques 13: 105-128.

Prévost, J.-G. 2009a. A Total Science: Italian Statistics, 1900-1945. Montréal: McGill-Queen's University Press. 
Prévost, J.-G. 2009b. "The Long Great War of the Italian Statisticians." Lettera Matematica 3 (1-2): 63-71.

Prévost, J.-G. 2016. "Statistical Theory, Scientific Rivalry and War Politics in Fascist Italy (1939-1943)." In Science Policies and Twentieth-Century Dictatorships: Spain, Italy and Argentina, edited by A. Gomez, A. F. Canales and B. Balmer, 159-177. London: Routledge.

Reuter, E. B. 1931. "Population." American Journal of Sociology 37 (1): 647-648.

Rottenburg, R., S. E. Merry, S.-J. Park, and J. Mugler, eds. 2015. The World of Indicators: The Making of Governmental Knowledge through Quantification. Cambridge: Cambridge University Press.

Saraiva, T. 2011. "Costruire il fascismo: autarchia e produzione di organismi standardizzati." In Storia d'Italia. Annali 26. Scienze e cultura dell'Italia unita, edited by F. Cassata and C. Pogliano, 203-239. Turin: Einaudi.

Saraiva, T., and M. Wise. 2010. "Autarky/Autarchy: Genetics, Food Production, and the Building of Fascism." Historical Studies in the Natural Sciences 40 (4): 419-428.

Scott, J. C. 1990. Domination and the Arts of Resistance: Hidden Transcripts. New Haven, CT: Yale University Press.

Secord, J. 1986. "The Geological Survey of Great Britain as a research school, 1839-1855." History of Science 24: 223-265.

Seo, M. G., and W. D. Creed. 2002. "Institutional Contradictions, Praxis, and Institutional Change: A Dialectical Perspective." Academy of management review 27 (2): 222-247.

Snowden, F. M. 2009. The Conquest of Malaria: Italy, 1900-1962. New Haven, CT: Yale University Press. Sofia, F. 1988. Una scienza per l'amministrazione. Assisi: Carucci.

Stapleford, T. A. 2009. The Cost of Living in America: A Political History of Economic Statistics, 1880-2000. Cambridge: Cambridge University Press.

Suchman, M. R. 1995. "Managing Legitimacy: Strategic and Institutional Approaches." Academy of Management Review 20: 571-610.

Suddaby, R., A. Bitektine, and P. Haack. 2017. "Legitimacy." Academy of Management Annals 11 (1): 451-478.

Tagliacarne, G. 1935. "Per una società italiana di statistica." Barometro economico italiano 71: 241.

Tazzioli, R. 2011. "I matematici tra scienza, politica e istituzioni." In Storia d'Italia. Annali 26. Scienze e cultura dell'Italia unita, edited by F. Cassata and C. Pogliano, 385-415. Turin: Einaudi.

Tooze, A. 2001. Statistics and the German State, 1900-1945: The Making of Modern Economic Knowledge. Cambridge: Cambridge University Press.

Treves, A. 2001. Le nascite e la politica nell'Italia del Novecento. Milan: LED.

Turner, R. S. 1993. "Vision Studies in Germany: Helmholtz versus Hering." Osiris 8: 80-103.

Vaara, E., J.Tienari, and J. Laurila. 2006. “Pulp and Paper Fiction: On the Discursive Legitimation of Global Industrial Restructuring." Organization Studies 27: 789-813.

Varni, A., and G. Melis. 1999. Burocrazie non burocratiche: Il lavoro dei tecnici nelle amministrazioni tra otto e novecento. Turin: Rosenberg \& Sellier.

Weingart, P. 1999. "Science and Political Culture: Eugenics in Comparative Perspective." Scandinavian Journal of History 24 (2): 163-177.

Woller, H. 1997. I conti con il fascismo: I'epurazione in Italia (1943-1948). Bologna: II Mulino.

Woolf, S. J. 1989. "Statistics and the Modern State." Comparative Studies in Society and History 31 (03): 588-604. 